\title{
BALANCING THE BOOKS: BROKERAGE POLITICS AND THE "ONTARIO READERS QUESTION"
}

\author{
Oisin Patrick Rafferty
}

In the fall of 1884, Ontario's minister of education, George W. Ross, announced an agreement between his department and three prominent publishing houses respecting the publication of a new series of public school readers. ${ }^{1}$ The new Ontario Readers were designed to spearhead the minister's new textbook strategy. They were assigned exclusively to the three publishers for a term of ten years, and were to become the sole authorized readers for use in the public schools. Despite the minister's best efforts to pre-empt public and political criticism of his course, and to assuage the fears and apprehensions of those who might be directly affected by it, his policy announcement nevertheless succeeded in raising the ire of certain parties in the province-among them, school trustees, ratepayers, and retail booksellers-many of whom suspected conspiracy and collusion between the government and private enterprise.

The Ontario Readers issue has received little specific attention from historians of education. If not completely ignored, it has at least been treated as only marginally germane to other themes, such as curriculum content or the tendency towards bureaucratic administration, which have been regarded typically as more central to the analysis of late nineteenth-century educational administration. ${ }^{2} \mathrm{~A}$ closer examination of the issue, however, reveals a confluence of educational and social history in several key areas. First, in terms of curriculum reform, this issue serves as a benchmark case in George Ross's incipient policy of centralization, rationalization, and course integration. Ross began to develop a policy of curriculum management that was very much informed by the tendencies of the late nineteenth-century business culture: that is, a policy by which control would be vested in the central authority, distribution would become more efficient due to the reduction in the numbers of authorized books, and the curriculum would be made more relevant by encouraging the integration of reading with other core subjects. Second, the readers issue was debated in the context of the late nineteenth-century tendency towards increasing economies of scale, and the concomitant reaction against trusts and combines. As such, the growing power imbalance between core and periphery, both in educational administration and in the economy at large, animated the discussion. Third, Ross's attempt to steer 
his course by means of brokerage politics tended to contribute to the very power imbalances that aroused opposition to his policy in the first place. His brokerage style failed to account for the resonating effects of government policy throughout the system, and the social relations engendered by it.

Trustees, educators, and booksellers across the province, whose positions and interests were touched by the department's new course, expressed their concerns collectively through their own cohesive social alignments. Both their complaints and the concerns that fuelled them hinted at their own awareness of an imbalance in power relations, symptomatic of a brokerage politics that was either unable or unwilling to embrace their needs and reflect their interests in public policy. Both the increased centralization of the department's decisionmaking and the rationalization of textbook publishing signalled a retrenchment of status inequality between local boards and the education department, and between booksellers and publishers, which resulted from the imposed limitations of the brokerage process itself. In the arena of business and government relations, the government was often viewed less as the legitimate guardian of the public interest, and more as a broker of business interests; and business was seen to be an enthusiastic collaborator with government in the project of shaping reform from above.

The Ontario Readers question was rooted in an earlier textbook controversy that beleaguered Adam Crooks's education department in 1882. With the intention of replacing the old National Series readers, a mainstay on the authorized booklist since Confederation, Crooks threw open a competition among publishers to have their own prepared readers authorized for use in the schools. Of the three firms that submitted tenders-Thomas NeIson \& Sons, W.J. Gage \& Company, and The Canada Publishing Company-only the latter firm's product, the Royal Canadian Readers (the only indigenous Canadian product of the three) failed to gain assent from the central committee. ${ }^{3}$ This omission angered critics, such as G. Mercer Adam, editor of The Canada Educational Monthly, who believed that the government should be encouraging home industry, particularly in the schools. ${ }^{4}$

In the aftermath of the central committee's decision, all three publishing houses canvassed the province, presenting their products directly to the local school trustees. Agents for Nelson and Gage competed for a share of the market, while The Canada Publishing Company sought to garner support among school trustees in order to pressure the department to reconsider. In so doing, the firm sponsored advertisements which echoed G. Mercer Adam's nationalist appeal to 
"encourage home industry and enterprise." The company managed to secure resolutions from a number of local assemblies to adopt its book if authorized. ${ }^{5}$

Meanwhile, allegations of wrong-doing sullied the competition between the other two publishers. James Campbell, whose publishing firm acted as agent for Thomas Nelson \& Sons, charged that certain public school inspectors-notably James L. Hughes of Toronto and John P. Miller of Huron-were abusing their positions and their influence by canvassing school boards on behalf of W.J. Gage \& Company. ${ }^{6}$ The Canada Educational Monthly went so far as to suggest that "not less than a dozen city and county Inspectors [were] violating the professional code" in this manner." The Canada Publishing Company and Wm. Warwick \& Sons likewise complained of the inappropriate use of inspectors as private agents, and of a conscious campaign of misinformation being carried out by Gage \& Company. ${ }^{8}$

For his part, W.J. Gage replied that his own firm's legitimate interests were in fact being hampered by the malicious political posturing of its rivals. In a lengthy letter to the minister, Gage protested that both the integrity of his firm and the quality of its product had been maligned. He reminded the minister that the public school inspectors were vested by law with the "duty of recommending what they deem the best of the properly authorized books," and accused Thomas Nelson \& Sons, along with its Canadian agent, James Campbell \& Son, of "impolitic interference." Such actions, he said, were "the fruitful source of nearly all the complications that have arisen in connection with the Reader question."

According to G. Mercer Adam, however, the real malaise lay not in the competitive process as such, but specifically in the central committee's unfortunate decision to authorize more than one series at a time. Throughout this ordeal, Adam had warned of the problems associated with "a plurality of Readers," and staunchly advocated the return to a single series under tight provincial controls. What most concerned him was the way in which the publishers appeared to be using the local school administrators as pawns in their competition. ${ }^{10}$ Thus, in January, 1884 , when George Ross revealed his intention to develop a single authorized series, Adam hailed this as the one "commonsense course." 11

In pursuing this course, Ross tried to correct the circumstance that had given rise to the publishers' battles and to the criticism generated in both the public and the educational press. At the same time, he sought to promote his own educational and administrative agenda. Ross envisioned a single, high-quality reader which would be used in all the schools in the province. To accomplish this goal, he had first to address the concerns of the publishers, who had already invested significant resources in the production and promotion of the current readers, and balance these concerns with those of educationists and local ratepayers. The publishers, Ross believed, would have to be given the opportunity to recoup their losses while, at the same time, trustees and ratepayers would have to be convinced of the long-term stability that would presumably follow this quick policy change. The resulting agreement signalled a compromise of sorts, and bespoke Ross's 
commitment to curricular rationalization and administrative efficiency. The introduction of the new readers promised to be the first plank in an overall strategy of streamlining the curriculum and of reducing the number of authorized books for any given course. Among other things, Ross's programme, by removing all ambiguity, was meant to discourage the use of unauthorized books in the classroom. 12

Besides the thrust of efficiency, however, the new policy also embodied two other significant themes of the 1880s: a new "scientific" approach to pedagogy, popularized by proponents of the "new education," and a larger commitment to Canadian content. With the aid of the new readers, teachers were encouraged to teach by means of object lessons whenever practicable. From the outset, the first-form primers guided pupils through the rudiments of basic phonics by instructing them to identify objects in the drawings that accompanied the lessons. ${ }^{13}$ In later forms, teachers were encouraged to enhance the practical relevance of subjects by integrating the curriculum. Thus, reading lessons could be used to provide appropriate bridges to other core subjects, such as science or history, whenever the material overlapped. Similarly, the readers' emphasis upon Canadian content, particularly in the early books, was an attempt to facilitate practical instruction through the use of idyllic rural motifs with which most Ontario school children could presumably identify, ${ }^{14}$ while at the same time satisfying the need for school reading materials that reflected Canadian realities and promoted a sense of Canadian identity.

The Ontario Readers were to be jointly published by Thomas Nelson \& Sons, W.J. Gage \& Company, and The Canada Publishing Company. Nelson thereafter sold the publication right to Copp, Clark \& Company, reportedly for about $\$ 20,000$. $)^{15}$ The agreement gave the three firms the exclusive right to publish the series for a period of ten years. The selling price during this time was fixed by the department. The contract also gave the department the right to inspect finished samples and to reject faulty work. ${ }^{16}$ By stipulating that the series be compiled in-house, and by keeping the plates as the property of the department, Ross reserved for himself strict control of the content and composition of the readers. He effectively strengthened his department's control over the substance of the reading curriculum, while at the same time rationalizing its distribution and dissemination.

The introduction of the new readers represented a potentially significant departure in relations between the education department and private enterprise. The department was now directly involved in the preparation of a whole series of textbooks. Three firms were awarded the simultaneous right to publish a single series. And furthermore, the awarding of an exclusive ten-year contract was a notable deviation at a time when one-year contracts, public tenders, and open competition for publication rights were the norm. Ross had, in effect, begun a novel experiment in the management of public contracts, in which open competition gave way to regulation, and private tenders to public franchises. Rather than selecting from a field of privately sponsored books, Ross farmed out the work to 
those firms that showed the interest and capacity to handle the production. For all intents and purposes, the three firms were now licensed to produce and distribute the department's own public school readers. ${ }^{17}$

Archibald MacMurchy, who succeeded G. Mercer Adam as editor of The Canada Educational Monthly, expressed immediate misgivings about the propriety of the government's course of action. While MacMurchy was sympathetic with "the difficulties the Minister had to face" in designing and executing the new policy, he was nevertheless troubled by the shape that policy took. ${ }^{18}$ MacMurchy argued that Ross's in-house preparation constituted a dangerous and overt interference with trade. "We must...place on record our disapproval of the agency by which the series has been prepared," noted the editor, "and our dissent from the idea that Government is justified in doing work that ought to be left to private enterprize [sic]." 19 Suggesting the possibility of "no little jobbery," he was suspicious that the department's new approach invariably held out "visions of fat things to departmental protégés, and no end of nice pickings to professional favourites of the Minister or needy hangers-on of party." 20 The minister, argued MacMurchy, had jeopardized the public interest by leaving the door open to political corruption.

In spite of his critics' charges, Ross insisted that his textbook policy was solidly in the public interest insofar as it "protected the public against unnecessary alterations and changes in the text of the Readers," and guaranteed the price of the series for the life of the contract. ${ }^{21}$ Moreover, the public would be protected against mechanical defects or declining standards of production, given the department's pledge to monitor the quality of the books printed. The book trade, too, would be protected by the government's provision of a guaranteed discount rate on all readers supplied to them by the publishers. ${ }^{22}$ But these assurances were not sufficient to placate a growing opposition to the new course. The two major Toronto dailies locked horns on this issue, the Globe applauding and endorsing the government's initiative, and the Mail scorning and condemning it. But Ross's critics also came from the very groups in society whose interests were supposedly advanced by his policy-namely, school trustees, educators, and independent booksellers. The reactions of these groups revealed the complexities and pitfalls of traditional brokerage politics in the modern state.

\section{III}

Ross's textbook reform, from the outset, was greeted with ambivalence by educationists and administrators. On the one hand, there was growing support for a practical, scientific approach to pedagogy, and even for a rational basis for curriculum development, as evidenced by numerous articles and letters submitted by schoolmasters to The Canada Educational Monthly. On the other hand, the 
minister's unilateral decision to produce the new readers, without allowing for local consultation or seeking local input, signalled a tightening of the central authority's control over the educational machinery of the province. Trustees and teachers, whom Ross did not consider capable of designing lessons appropriate to the modern curriculum, ${ }^{23}$ were further excluded from the process, and the job was given to a hand-picked committee of three senior educators. The surviving evidence is sketchy on the reactions of local bodies to the widening disparity in their relations with the education department, and to the minister's handling of the readers question in particular. However, some tentative speculations may be made.

It is true that the prior competition among the publishers had meant that local trustees and educators were subjected to certain pressures and annoyances implicit in the canvassing process. However, the process itself suggested a lingering degree of political, and even educational, autonomy on the part of trustees, who could ultimately select the books that they felt were most appropriate for the schools of their districts. The threat posed by the introduction of the Ontario Readers was that this autonomy of choice would be undermined by the exigencies of rational administration. Moreover, if the minister could be taken at his word, this streamlining would affect not only the teaching of phonics, grammar, reading, and literature, but eventually all other subjects as well. ${ }^{24}$ Clearly Ross's commitment to rationalization represented a threat to local prerogative. But to deny trustees and teachers the ultimate choice of classroom materials, within the prescribed guidelines, was seen also as running counter to the ideal that schools should be responsive to local needs.

No less important, however, was the concern expressed by some trustees about the effects of Ross's policies on their constituents - the parents who would invariably bear the cost of the government's policy. The trustees of Oneida Township, in Haldimand County, took this position in a petition drafted in May, $18844^{25}$ They appealed to the minister on the grounds that their board had already adopted the recently authorized Canadian Readers, that "a very large number" of these books had already been purchased by parents, and that the books were already being used in the schools of the district. The trustees claimed that the proposed change, since it would render the previous books virtually useless, "would necessarily cause another outlay which would be vexatious to parents and a source of complaint against us who are their representatives in school matters." Moreover, they testified that the series that they had adopted only months earlier was "giving entire satisfaction." 26

Added to those costs implicitly involved in the transition was the higher cost of the new series relative to previous sets. Not only would parents be obliged to replace their children's old books with the new ones, but they would also have to buy the new ones at a premium price. While Ross denied that the Ontario Readers were dear, his critics were quick to point out that at a cost of $\$ 1.35$ for five books covering the four forms of public school, they were fully five cents more expensive than Gage's Canadian Readers, which had been adopted already 
by a number of boards. In London the public school trustees announced that they would continue to use the old series as long as was legally permissable, "unless some modification is made in the prices and discounts." 27 Ross, however, held firmly to his contention that "the purpose of the book is educational, and that a small additional outlay is of no consequence compared with the educational results." ${ }^{28}$ While Ross insisted that the difference in price amounted to only 1.5 cents per pupil per form, critics nevertheless regarded his blithe dismissal of ratepayers' and trustees' concerns as arrogant and cavalier.

Members of the Conservative opposition in the legislature were eager to turn the minister's apparent arrogance to their own political advantage and quickly undertook the task of challenging Ross on behalf of local officials. Given the economies of scale involved in the tripartite agreement with the publishers, they contended that the whole series could have been produced for $\$ .51$, but was being sold for $\$ 1.35$. Once the retailers' discount was taken into account, they concluded that the publishers were netting a combined profit of about $\$ 370,000$ over the life of the contract from this venture alone. "This is the price the people are paying for the Government's blundering," chided an 1886 Conservative election pamphlet. ${ }^{29}$ The conclusion was that the people were being made to pay the cost of the minister's "policy adjustments" because, to echo Ross's own words, "the publishers had to be compensated" for losses they suffered as a result of the transition. $^{30}$

This was a recurring theme in the debate during 1885 and 1886 . Its most fervent expression came from the retail booksellers across the province who saw in the education department's franchising arrangement with the publishers a thinly veiled attempt to form a textbook trust, and who objected bitterly to the formation of a combine of publishing interests created and legitimized by legislative fiat. To some booksellers, the tripartite agreement represented an unholy alliance of publishing magnates conspiring with the education department to consolidate trade and restrict competition. Retail booksellers saw their vested interests in the book trade as being linked both to consistency in the authorization of school books, and to an open competition among publishers to secure that authorization. Then, and only then, could retailers avoid the losses associated with holding inventories of books no longer authorized for use in the schools, and be assured of securing adequate discount rates on books purchased from the publishers, from which their own profits were generated. ${ }^{31}$

Independent booksellers were deeply concerned that the process through which the Ontario Readers were introduced, and the policy direction implied by it, portended more costly adjustments to come. Indeed, if this new policy was not at least cautiously regulated, it could place them in a situation of perpetual disadvantage in their dealings with the publishers concerned. Not only did it mean stockpiled inventories of unsaleable books, but also limited leverage in negotiating discount rates with the publishers. They believed that the price to be paid for rationalization was being bome, not only by local ratepayers, but also by small, independent shopkeepers. Spokesmen for the trade viewed the situation 
as nothing short of a battle between corporate oligopoly and free enterprise, and were determined not to become mere client firms or satellites of the Torontobased publishers. To the members of the book trade, the fact that the three firms played an active role in dictating the terms of the accord--that these firms in fact conspired to limit competition and fix prices-constituted damning evidence of market manipulation. The retailers regarded the three textbook franchises suspiciously as a single combine, sanctioned by the minister to help compensate the publishing houses for their losses, and were angered that no effort had been made in advance to compensate private retailers who, acting in good faith, had purchased quantities of the short-lived Gage and Nelson readers. Their own exclusion from Ross's brokerage process led them to the conclusion that dirty dealings were afoot.

In January, 1885, over seven hundred independent booksellers met in Toronto to protest the government's handling of the school books issue and, in particular, to voice a united objection to the creation of a publishing combine with essentially monopolistic interests in the Ontario Readers. As a result of this meeting the Ontario Booksellers' Association was formed, and Mr. T.J. Day elected its first president. The new trade association was mandated to act as a lobby on behalf of the private retailers, and to provide an organizational network to join together booksellers from across the province "for the general benefit of the trade. ${ }^{32}$ The broad coalition of private retailers was a clear expression of the will for mutual indemnity. It signified a sense of common grievance, and a commitment to common action and mutual benefit. To resist what they understood to be a combination, retailers themselves opted for collective action in defence of the integrity of their marketplace, which they believed had been undermined. ${ }^{33}$ Theirs was an outward response to a visceral sense of disaffection from a process to which they were denied access, and through which their material interests were disregarded. In the end, they lobbied above all for inclusion. The booksellers' association was complemented, in its campaign, by the trade journal Books and Notions, edited by the stationer and printer, J.J. Dyas.

The booksellers' first official motion revealed the extent of their disaffection and posed the first test of the strength of their association. At their inaugural meeting, they unanimously passed a resolution "to have no further dealing with the three firms so long as the monopoly existed." ${ }^{34}$ However, while they may have had the political will to carry out such a proposal, they apparently lacked the economic will; the resolution was never successfully implemented and was quietly dismissed. Realizing the difficulties involved in launching a successful boycott, they turned instead to political lobbying in an attempt to negotiate terms of distribution that would be more acceptable to the members of the trade. In February, 1885, the booksellers' association appointed a delegation to wait upon the education minister in order to plead the retailers' case. The delegation, however, was unsuccessful in "securing any better terms from him or the publishers." 35 
Thereafter, the demand for "better terms" stood at the heart of the trade's resistance to the readers contract. Whereas the contract provided lucrative and guaranteed profits to the giant publishing houses, it simultaneously hampered the returns of small retailers. While JJ. Dyas called this "a tax on [the] parents of Ontario," the booksellers themselves. The lion's share of the cost was being borne by the retailers in the form of lower discount rates from the publishers. Since the selling prices of textbooks were normally set by the publishers and approved by the department, booksellers were not free to add their own retail mark-up. Discounts to the trade represented their total operating costs and profit margins. Lobbyists for the booksellers' association complained that the education department's publishing accord had frozen the discount at a base rate of $20 \%$, with an additional $5 \%$ on orders of $\$ 1,000$ or more. In the past, noted Dyas, the trade had been able to negotiate discounts of up to $30 \%$ and $15 \%$ respectively. This, however, was contingent upon a state of free competition among the publishers. ${ }^{37}$ On this count, the booksellers' case was clear. They demanded "liberty of trade from the thraldom of the autocrats, and compensation for the losses sustained in old useless Readers." 38

To men like Dyas and Day, the social costs of trusts and combines seemed all too apparent. The consolidation of publishing interests in the readers trade symbolized a retrenchment of status inequality between booksellers and publishers. This inequality was accentuated by the booksellers' failure to win any concessions from Ross. "The publishers are amply provided for," Dyas told his peers, "but the retailers? Pshaw, what of them! They are only a few hundred storekeepers, very well in their way, but not worthy of any consideration. ${ }^{39}$ The booksellers, operating in what Richard Edwards has labelled the peripheral economy, ${ }^{40}$ lacked the same access to political decision-making that the more influential publishers apparently enjoyed. Dyas saw the booksellers' association as the vehicle to correct this situation. Through the pages of Books and Notions, the booksellers were hailed as "an organized set of men who know their rights, and dare maintain them." Furthermore, Dyas expressed his confidence that "a body of more than 800 should, by proper combination, more than outlive in length of endurance the affiliated body of autocrats." ${ }^{41}$ Despite early disappointments, the resolve of the booksellers' coalition appeared to strengthen, prompting The British and Colonial Printer and Stationer to proclaim: "Canada is finding out that, in the book trade, union is strength." 42

The booksellers' association persistently pressed its official position that the trio of publishers constituted a business trust in the market for primary readers, and that the same monopolistic tendencies that tainted the readers trade threatened to infect the markets for other types of school-books. The higher retail prices and lower discount rates were entered as evidence of the plutocratic behaviour of trusts and combines at the expense of small business and consumers. The booksellers, however, were careful to keep the focus on combines, and not on the individual firms themselves. They contended that monopoly is as monopo- 
ly does. From this vantage point, the spokesmen for the booksellers could decry the evils of monopoly without directly casting aspersions on the integrity of the three firms with whom they would otherwise be conducting business as usual. According to Books and Notions, each of the three houses-Copp, Clark \& Company, W.J. Gage \& Company, and The Canada Publishing Company - had established reputations individually with the book trade as honest brokers and fair dealers. Yet in combination their dealings were suspect. "What demon is there in the bond of monopoly," puzzled the editor, "that men otherwise fair and just are so exacting in their dealings with the self-same people."43 Over the course of their public campaign, the booksellers' allegations of monopoly transcended the level of mere rhetoric designed to convince others of the injustice of the situation and the equanimity of their own position. Instead these allegations became an accurate reflection of how the retailers viewed their own position relative to the publishers.

When pressed, in March, 1885, to address the booksellers' charges, Ross offered a fatalistic response that failed to satisfy his critics. Trusts and combinations were rapidly becoming commonplace in North American business. Regardless of a pre-existing state of open competition, noted Ross, combinations and price-fixing arrangements were occurring among "railway operations, cotton and woolen [sic] manufactures and oil refiners." And in the case of the Ontario Readers, he suggested that "under any system calculated to secure uniformity of text-books it is impossible to prevent a monopoly." 44 Yet, in his own defence, Ross added that in negotiating the contract he had anticipated "the evil of a combination, which otherwise we might not be able to control," and therefore had "made such a contract that if the publishers do combine, they cannot inflict any injury upon the public interests concemed." Besides, insisted Ross, the three firms were "not in partnership" and were, in fact, "competing with each other.," The contract, while it controlled the terms of publication and distribution, also established a new arena for competition which the minister believed would serve both the public and the educational interests of the province. The terms of the accord ensured that quality would replace price as the primary basis of competition. Ross argued that "if by superior binding or by superior paper or in any other way one can secure a larger sale for his books than the other, the public will have the advantage of such competition." 46 To answer those critics who charged that this sort of combination would inevitably result in books of lower quality at higher prices, Ross maintained that the result would be books of higher quality at fixed prices.

Nevertheless, there remained the concern that the suppression of open competition in the readers trade would encourage the manufacturers to cut comers in materials and workmanship in order to reduce production costs, thus vitiating the quality and durability of the books produced. By the summer of 1885 , local booksellers were grumbling that they had to deal with the complaints of parents concerning readers of poor quality, not durable enough to withstand the wear and tear of their children's nomal use. Not only did parents complain 
about the price, but they also complained that "they generally have to use several before the child passes." 47 Teachers, too, called into question the quality of workmanship. Edward Trought, a teacher from Peel County, returned to the education department a "typical" sample of a second-form reader, published by W.J. Gage \& Company, which was coming apart because it was glued, not stitched, to the binding. This sample, he informed Ross, was typical of the Gage readers in his school. Comparing Gage's product to that of Copp, Clark \& Company, he observed that the Copp, Clark books were in fact "sewed to tapes at the back," and were consequently more durable for school use. ${ }^{48}$

By the terms of the contract, the department reserved the right to reject any books deemed substandard in workmanship or materials. This proviso was meant to ensure that certain standards of quality would be maintained throughout the life of the accord. The task of quality control fell on the shoulders of George $E$. Thomas, the Assistant Queen's Printer, and his associate, H.M. Wilkinson. In their report on the first edition of the Ontario Readers, Thomas and Wilkinson concluded that in terms of paper, printing, and binding, the samples submitted by all three firms were "not up to the standard of first-class work." However, because of the immediate demand for this edition, the books were allowed to pass, on the condition that the defects be remedied in succeeding editions. ${ }^{49}$

The publishers responded that any defects that did occur in the first edition were due largely to the haste in which they were compelled to produce the books in order to meet the demand caused by the withdrawal of the old readers. The publishers complained of having to farm out work to small independent binderies and pay "the increased wages workers demand for overtime." ${ }^{50}$ Between 1885 and 1889 , however, Thomas and Wilkinson continued to point out various persistent defects in the readers submitted by all three firms. Some typical problems included weak binding, low-grade paper quality, inconsistent toning, smudged print, and "broken letters." For the most part, the publishers were apologetic when such problems were brought to their attention, and usually attributed the errors to accidental oversights, not unknown to such lengthy production runs. ${ }^{51}$ Nevertheless, the persistence of some of these quality defects and production inconsistencies led Thomas to conduct on-site inspections of the printing shops and binderies, to forestall any problems before they started. ${ }^{52}$

The production standards of the readers were also challenged from the ranks of organized labour, through an attack aimed specifically at W.J. Gage \& Company. In the fall of 1886 , a deputation of bookbinders, led by Robert Glockling, contacted Ross concerning what was considered to be the inferior work done on the Ontario Readers by Gage. ${ }^{53}$ With the technical authority of skilled craftsmen, they charged that Gage's books were inferior both in workmanship-the work "having been performed by Unskilled hands"- and in materials - the use of low-grade mull, inadequate to support the wilk wire stitching. ${ }^{54}$ Seen in the context of the mechanization of the bookbinding and printing trades in the 1870 s and 1880 s, as well as the organization of the bookbinders by the Knights of Labor in 1886, these charges imply the craft's 
resistance both to the introduction of new binding machines, notably the Brehmer machine, and to the concurrent use of unskilled labour to operate them. This conclusion is borne out by the Queen's Printer's Report for 1886, in which Thomas and Wilkinson concluded that "the cause of complaint is inferior workmanship and not so much inferior material." $" 55$ The company, for its part, fought back by discrediting its accusers without specific reference to their charges. In a note to Ross, Gage \& Company explained that the allegations were raised by "several dissatisfied workmen whom we had the occasion to dismiss." The note concluded by positing that the names of those advancing the workers" case, notably D.J. O'Donoghue and A.F. Jury of the Trades and Labour Council, would be "sufficient to show that [the] complaints they have made are wholly unworthy of credence, and are only made with a view to furthering personal interests." 56 Indeed, the reciprocal antagonism between capital and labour was yet another feature of late nineteenth-century social politics that found an outlet for expression in the "Readers Question."

\section{IV}

In 1890 , in accordance with the terms of the original tripartite agreement, a commission was appointed to review the record of the Ontario Readers over the first half of the contract life. The commission's primary mandate was to investigate, and if necessary to arbitrate, the pricing and discount provisions. For the most part, the original vehemence of the public resistance to the government's course had subsided gradually since 1886 , but the onset of the commission helped to revive some of the criticism. The Mail, for instance, paused to remind its readers of the issues involved, and suggested that if Ross had left the books "open to competition" in the first place, then the "solemn farce of arbitration would not have been necessary." ${ }^{57}$ The commission heard evidence from each of the three publishing houses and from a special delegation of the Ontario Booksellers' Association, now led by the St. Mary's book dealer, H. Fred Sharp. ${ }^{58}$

The Textbook Commission's report was published in June, 1891. In the report, the committee-Richard Brown, James Bain, Jr., and Edward Morganrecommended a few adjustments to the details of the existing contract. After weighing the sales of books in each of the four forms against the selling prices of the books at each level, they suggested only a partial amendment to the price schedule. While they determined that the publishers were not making an unreasonable profit on the sales of the First Reader, Parts One and Two, nor on the Second and Third Readers, they were netting excessive profits on the sale of the Fourth Reader. Ironically, it was the Fourth Reader that had the smallest annual production run in the series; only 20,000 were sold in 1890 , as opposed to 100,000 copies of the First Reader, Part One. Moreover, only $25 \%$ of students in the fourth 
form were using new books, as opposed to $90 \%$ in the first form. ${ }^{59}$ Nevertheless, the committee recommended a five-cent reduction in the price of the Fourth Reader, bringing it from $\$ .50$ to $\$ .45$ per copy. ${ }^{60}$ The committee also addressed the main grievance of the booksellers. While they advised that the discounts to the trade be held at $20 \%$ on the First Reader, Parts One and Two, they otherwise recommended that, based on the standard practices observed in other textbook arrangements, the discounts on the Second, Third, and Fourth Readers be increased to $25 \%{ }^{61}$ In the course of arbitration, the concerns of ratepayers and retailers had been weighed against those of the publishers, and in the final verdict, they were (at least partially) vindicated.

In 1896, the Ontario Readers contract was renewed for a second term of ten years. With the exception of a few newspaper editorials, however, the contract renewal passed without significant opposition or incident. ${ }^{62}$ By 1901 , even the Conservative Toronto News had to concede that "there are weaker points in the armour of the Ross Government than the school book monopoly." 63 By the early 1890 s, the issue had run its course, and by 1906 , so too had the "new" Ontario Readers. In that year, the new Conservative education minister, R.A. Pyne, revived concerns that the books were being sold at an exorbitant profit, and established a commission to look into the matter. And in 1907, Pyne appointed a committee of nine men-all of them school inspectors or principals - to prepare a new set of public school readers. In the interim, he awarded an exclusive eighteen-month contract on the old Ontario Readers to The Canada Publishing Company, the books to be sold at a markedly reduced price. The series that had sold for $\$ 1.35$ in 1885 was offered for only $\$ .49$ in $1907 .^{64}$

In the early years of Ross's stewardship of the education department, then, the readers question aroused considerable comment and excited some stalwart opposition. Ross approached the issue of textbook and curricular reform with three aims in mind: to standardize and rationalize the use of textbooks across the province; to promote efficiency in their production and distribution; and to assert the education department's effective control over subject matter and curriculum. ${ }^{65}$ The franchising of the readers trade, by which the publishers were licensed to produce and distribute books prepared and controlled by the department, was essentially an experimental measure towards these goals. But this search for efficiency and control, which motivated the minister's reforms, clearly antagonized some members of groups whose interests were directly affected by the policy. That the minister, in explaining his new policy (and the goals underlying it), failed to accommodate the apprehensions of people throughout the system, and was ill-prepared to address satisfactorily the concerns of those who opposed his new course, belies the notion of a smooth and workable 
consensus through the mechanism of traditional brokerage politics. Instead he left himself open to charges ranging from "colossal vanity" to political corruption, as in The Empire's claim that he had "done a lot of tinkering with the public school system to centralize power in his department, so that he can use it as a political machine." ${ }^{66}$ Indeed, a genuine accommodation of disparate interests was unlikely unless the parties involved were themselves balanced in terms of power and influence.

While the centralization of control was the hallmark of efficiency and rationalization for both government and business in the 1880s and 1890s, it was often seen as the bane of those on the margins of power and influence. The consolidation of power at the centre signalled the retrenchment of status inequality between the centre and the periphery. In this sense, the trustees' complaints of the unnecessary cost and inconvenience of the new readers concealed deeper concerns about their own political accountability and diminishing local autonomy; while the booksellers' allegations of monopoly revealed their own disquietude about their vulnerable economic position and their apprehensions and frustrations about their lack of political leverage. If openness, inclusion, and consent were found to be wanting in the government's management of public affairs, this ultimately led to charges of unfair dealings-mpecisely what brokerage-style politics was intended to avoid.

\section{NOTES}

* The research for this paper was financially assisted by the Social Sciences and Humanities Research Council of Canada. Earlier drafts were read by Laura Holland, Liliane Racheter, John C. Weaver, R.D. Gidney and W.P.J. Millar. I wish to thank them, and the journal's reviewers, for their comments, criticisms, and editorial assistance.

1. Archives of Ontario, Education Department Records thereafter RG2], D9A, Box 2, Copy of an Order in Council approved by His Honour the Lieutenant-Governor, 18 Dec. 1884.

2. See, for instance, Robert M. Stamp, The Schools of Ontario, 1876-1976 (Toronto: University of Toronto Press, 1982), 32.33; Viola Elizabeth Parvin, The Authorization of Textbooks for the Schools of Ontario, 1846-1950 (Toronto: University of Toronto Press, 1965), 68-69; Gerald Killan, David Boyle: From Artisan to Archaeologist (Toronto: University of Toronto Press, 1983), 73-74; George S. Tomkins, A Common Countenance: Stability and Change in the Canadian Curriculum (Scarborough: Prentice-Hall Canada Inc., 1986), 235-37; D.A. Lawr and R.D. Gidney, "Who Ran the Schools? Local Influence on Educational Policy in Nineteenth-Century Ontario," Ontario History 62, 3 (Sept. 1980): 134-36.

3. For a more detailed discussion of this issue, see Parvin, The Authorization of Textbooks.

4. As early as 1879, Adam began to make his appeal for Canadian content in school reading materials. See, for instance, G. Mercer Adam, "Our School Manuals," The Canada Educational Monthly [hereafter CEM] I (Jan. 1879): 35 . He continued to promote this campaign for home industry until 1883 , when he resigned the editorship 
of CEM. See also, "Teachers' Associations Chronicle of the Month," CEM IV (Mar. 1882).

5. These advertisements appeared in CEM. See, for instance, CEM V (July-Aug. 1883). Resolutions of local teachers' associations appeared regularly in CEM. See CEMV (Nov. 1883); 446, for the resolution of the South Wellington and Guelph City Teachers' Association.

6. RG2, D9A, Box 2, James Campbell to A.S. Hardy, 1 Aug. 1883.

7. "Editorial Notes: Unprofessional Conduct," CEM V (July-Aug. 1883): 312.

8. Advertisement printed in CEM V (Nov. 1883). Also see the bulletin by Wm. Warwick \& Son, printed in CEM V (Nov. 1883).

9. RG2, D9A, Box 2, W.J, Gage to G.W. Ross, 6 Feb. 1884.

10. "The Question of the School Readers," CEM V (July-Aug. 1883): 308-10.

11. "The Reader Question," CEM VI (Jan. 1884): 41.

12. See "Uniformity of Text Books," The Globe, 30 Apr. 1886, 4. Also, there is ample evidence in the minister's textbook correspondence and memoranda (RG2, D9A) of the concern that many schools were persisting in the use of unauthorized books for classroom instruction. Public School inspectors were repeatedly told to discourage this practice and to report those teachers and schools using unauthorized texts. See, for instance, RG2, D9A, Box 2, "Circular to Public School Inspectors, Trustees and Teachers from Adam Crooks, Minister of Education, 5 January, 1882"; and in Box 3, Alexander Marling, "Text Books Authorized for Use in Public and High Schools and Collegiate Institutes, also in the Training Schools," 1887 (Circular no. 27).

13. The Ontario Readers, First Reader, Parts One and Two (Toronto: The Canada Publishing Co., 1885).

14. The Ontario Readers, Third Reader (Toronto: The Canada Publishing Co., 1885), preface. See also, Stamp, The Schools of Ontario, 33; and Tomkins, A Common Countenance, 237.

15. Books and Notions 1 (Dec. 1884).

16. RG2, D9A, Box 3, James Campbell \& Sons to Mr. W. Johnston, Barrister, 18 Sept. 1884.

17. In 1886, Ross commissioned three Toronto artists to prepare a drawing book for use in the public schools, and adopted a similar policy of retaining the plates and franchising the production. This time the extended contract was awarded to a single firm, the Methodist Publishing Company. See The Globe, 12 Apr. 1886, 4, and 17 Apr. 1886, 4. Franchising public contracts was becoming a significant feature of business and government relations in the late nineteenth century. On the use of public franchising in another context, see Charles W. Cheape, Moving the Masses: Urban Public Transit in New York, Boston and Philadelphia, 1880-1912 (Cambridge: Harvard University Press, 1980), esp. chaps. 6-7.

18. "The School Readers Again," CEM VII (Feb. 1885): 62.

19. "The Department and the School Readers," CEM VI (Dec, 1884): 510.

20. Ibid., 509 .

21. "The Reader Question: Speech Delivered by the Hon. G.W. Ross, Minister of Education, in the Legislative Assembly of Ontario, March, 1885," AO Election Pamphlet, no.33, microfilm B 30-1: 9, 11.

22. Ibid., 8-9.

23. Tomkins, A Common Countenance, 236.

24. Parvin, The Authorization of Textbooks, 73. 
25. RG2, D9A, Box 2, Petition of the Trustees of S.S. No. 10, Township of Oneida, County of Haldimand, 6 May 1884.

26. Ibid. On the attitudes of rural school trustees, both positive and negative, towards the rationalizing and centralizing tendencies of the education department in the nineteenth century, see R.D. Gidney and W.P.J. Millar, "Rural Schools and the Decline of Community Control in Late Nineteenth-Century Ontario," Proceedings of the 4th Annual Agricultural History of Ontario Seminar, 1979: 70-91.

27. "Letter to the Editor of Books and Notions, from the Books and Fancy Trades of London, dated 6 January, 1885," Books and Notions I (Jan. 1885): 97.

28. "The Reader Question: Speech Delivered by Hon. G.W. Ross, Minister of Education...March, 1885," AO Election Pamphlet, no. 33, microfilm B 30-1: 25-26.

29. "Facts for Electors: The School Book Monopoly," AO Election Pamphlet no. 75, microfilm B 30-1: 3 .

30. lbid., 2 .

31. "The New Ontario Readers," Books and Notions I (Jan. 1885): 92.

32. Books and Notions I (Feb. 1885): 108. For a brief examination of the meanings of "associationalism" in the late nineteenth century, see Dana F. White, "Education in the Turn-of-the-Century City: The Search for Control," Urban Education 4, 2 (July 1969): $169-82$.

33. They did not, however, endorse other forms of collective resistance which purportedly challenged the structure of the marketplace itself. I think that the distinction is important. In 1885, when the Knights of Labor called for a boycott of the Toronto Telegram and asked news dealers to do likewise, the editor of Books and Notions reflected: "Combination as long as it is kept within legitimate bounds is wise and right, but when it goes beyond that then it becomes a question for the people at large to decide whether or not it will be tolerated." Books and Notions II (Nov. 1885): 56.

34. Books and Notions I (Mar. 1885): 122.

35. Ibid. See also, The Globe, 13 Jan. 1885, 3.

36. "Trade Discounts," Books and Notions I (Mar. 1885): 124-25.

37. "The New Ontario Readers," Books and Notions I (Jan. 1885): 92; also see, "Trade Discounts," Books and Notions I (Mar. 1885): 124.

38. "Fair Play to All," Books and Notions I (Feb. 1885): 108.

39. Ibid.

40. Richard Edwards, Contested Terrain: The Transformation of the Workplace in the Twentieth Century (New York: Basic Books, Inc., 1979), chap. 5.

41. "One Unjust Discount Improved," Books and Notions I (Mar. 1885): 125.

42. Quoted in Books and Notions II (Oct. 1885): 97.

43. Books and Notions II (Aug. 1885): 10.

44. "The Reader Question, Speech Delivered by the Hon. G.W. Ross, Minister of Education,...March, 1885," AO Election Pamphlet no. 33, microfilm B 30-1: 14 and 13 respectively.

45. Ibid. During the election campaign in the fall of 1886 , Ross offered a clearer, more cogent explanation: "There can be no monopoly in the true sense of the term except when the monopolists themselves regulate the price of the article, as do the cotton lords and certain other large manufacturers." See G.W. Ross, "The Progress of Our Schools, Text Books, and Religious Instruction," Speech of the Minister of Education at his Nomination, 11 October, 1886, AO Pamphlet, 1886, no. 43 (xeroxed).

46. Ibid., 13 .

47. Books and Notions I (June 1885): 175. 
47. Books and Notions I (June 1885): 175.

48. RG2, D9A, Box 3, Edward Trought to G.W. Ross, 22 Oct. 1885.

49. RG2, D9A, Box 3, George E. Thomas and H.M. Wilkinson, "Report on the Second Reader, Ontario Series, as printed and bound by Messrs. Gage \& Co., Copp Clark $\&$ Co., and The Canada Publishing Company," (handwritten), 5 Apr. 1885.

50. RG2, D9A, Box 3, Copp Clark \& Company, W.J. Gage \& Company, and The Canada Publishing Company to G.W. Ross, 28 Aug. 1885.

51. RG2, D9A, Box 3, W.J. Gage \& Co. to G.W. Ross, 13 Jan. 1887; Alexander Marling to W.J. Gage \& Co., 27 Mar. 1888; W.J. Gage \& Co. to Alexander Marling, 31 Mar. 1888. RG2, D9A, Box 5, G.E. Thomas to G.W. Ross, 6 Feb. 1889; Copp Claxk \& Co. to Alexander Marling, 9 Feb., 1889.

52. RG2, D9A, Box 5, G.E. Thomas and H.M. Wilkinson, Report to the Honorable the Minister of Education in Regard to a General Inspection of the Authorized TextBooks at the Respective Publishers' Places of Business or Manufacture (Toronto 1889): 93-101.

53. RG2, D9A, Box 4, R. Glockling to G.W. Ross, 4 Oct. 1886; G.E. Thomas to R. Glockling, 16 Oct. 1886. In that same year, Robert Glockling, himself a bookbinder and long-time labour activist, ushered the Bookbinders' Benevolent Society into the Knights of Labor. See Gregory S. Kealey, Toronto Workers Respond to Industrial Capitalism, 1867-1892 (Toronto: University of Toronto Press, 1980): 324.

54. RG2, D9A, Box 3, A.F. Jury to G.W. Ross, 1 Nov, 1886 [emphasis in original].

55. RG2, D9A, Box 3, "Report of Queen's Printer," by G.E. Thomas and H.M. Wilkinson, 5 Nov. 1886 [handwritten, emphasis in original].

56. RG2, D9A, Box 3, W.J. Gage \& Co. to G.W. Ross, 23 Nov. 1886.

57. RG2, D9A, Box 9, Clipping File, "Education Department: A Glance at the Facts of Educational Administration in Ontario,"The Toronto Daily Mail, 21 Jan. 1891.

58. RG2, D9A, Box 5, H. Fred Sharp to G.W. Ross, 28 Mar. 1890.

59. RG2, D9A, Box 5, "New Readers Annually Introduced into Schools," memo by H.M. Wilkinson, 17 Feb. 1892.

60. RG2, D9A, Box 6, Report of Arbitrators Richard Brown, James Bain, Jr., and Edward Morgan on Ontario Readers Arbitration, 13 June 1891, 3-4.

61. Ibid.; RG2, D9A, Box 6, J.L. Miller to G.W. Ross, 18 June 1891.

62. Parvin, The Authorization of Textbooks, 68-69. See also, RG2, D9A, Box 9, Ross Text Book Policy Clipping File, for press reactions.

63. The Toronto News, 17 July 1901, reprinted in "Reply to Criticism Concerning Text Book and Other School Questions," AO Pamphlet, 1901, no. 26, 15.

64. RG2, D9A, Box 8, R.A. Pyne to G.E. Broderick, 26 Oct. 1907.

65. Parvin, The Authorization of Textbooks, 73-74. Tomkins, A Common Countenance, chap. 12.

66. RG2, D9A, Box 9, Ross Textbook Clipping File, "Mr. Ross Must Retire," The Empire (Toronto), 8 Jan. 1894. 